\title{
Pesan Dakwah Jeiri Al-Bukhori di TV One
}

\author{
Suharmoko \\ Dosen Institut Agama Islam Negeri Sorong \\ suharmoko@gmail.com
}

\begin{abstract}
The generation of rabbani is a generation of godliness and monotheism, and among them have resignation, patience and positive thinking. This understanding is often uttered by preachers such as Jefry al-Bukhari through various media including film and television shows. Jefry al-Bukhari uses TV media as a means simpler and more practical reason. Likewise movie, TV media is also an audiovisual media, meaning that it can be heard and seen at the same time. Most Indonesian television is used as the entertainment arena and the main source of information. In some areas, especially in Indonesia, many people spend their time watching television. If Islamic da'wah can utilize this media effectively, then automatically the spreading of da'wah will be wider and the religious impression it creates will be deeper. Actually television is a combination of radio and movie, because this media can deliver events in the form of live images with sound even with color when the event takes place. Therefore the movie deficiencies of its actuality can be covered up. In short, the uniqueness of radio and movie are gathered collectively in television and conversely the deficiencies in radio and film, on television are not found. Excluding the advantages contained in newspapers, or other printed medium that we can not find on this television. Currently, not a single second has passed without television shows both nationally and internationally with a variety of sophisticated communication devices. And there is not a single region that can be reached by this media. To the extent that this tool has transformed this big world into a large village (global village). In particular, Muslims in our country, however, have not been maximized to take advantage of this wasilah because it has been hit by the high cost that must be invested.
\end{abstract}

Keyword: promiscuity, awareness and da'wah 


\section{Pendahuluan}

Dorongan seksual yang sedang bergolak di kalangan remaja seringkali menyebabkan remaja tidak memiliki pemikiran yang panjang. Remaja lebih memilih melampiaskan hasratnya ketimbang memikirkan dampak negatifnya. Padahal akibat dari kenikmatan sesaat itu menyebabkan dirinya menderita selama-lamanya, terutama pada remaja perempuan apabila sampai hamil. Derita remaja perempuan ketika hamil akibat seks bebas dua kali lebih berat bahkan mungkin sepuluh kali lebih berat dibandingkan yang dialami remaja laki-laki. Sebab remaja perempuan di samping harus menanggung malu kepada keluarga dan masyarakatnya, kehilangan masa depannya karena biasanya menyebabkan putus sekolah, kerepotan mengurus anak pada umur yang masih belia tanpa adanya seorang ayah di sampingnya, juga ia harus tetap mempertanggungjawabkan perbuatannya di hadapan Allah di hari perhitungan nanti. Sedangkan derita remaja laki-laki lebih bersifat ukhrawi, itupun kalau ia tidak bertaubat. Sebab kaum laki-laki tidak mengandung, sehingga sungguhpun telah melakukan zina tidak diketahui oleh masyarakat. ${ }^{1}$ Karena itu, seharusnya remaja puteri memiliki pemikiran yang lebih panjang agar tidak terjerumus kepada seks bebas atau perzinaan. Insya Allah jika remaja puteri dapat tahan terhadap godaan, maka perzinahan tidak akan terjadi dan masa depan dapat terselamatkan. Demikian juga remaja putera, jangan mentang-mentang karena tidak memiliki risiko dunia, lalu dengan seenaknya mengumbar nafsu. Ingat tidak semua taubat manusia diterima dan azab Allah di akhirat sangat pedih.

Ketika sedang berduaan dengan sang kekasih biasanya remaja merasa seakan dunia ini hanya milik berdua. Sehingga ia melakukan apa saja yang disebutnya sebagai perwujudan kasih sayang kepada kekasihnya. la tidak ingat saat sendirian, sebenarnya berduaan, saat berdua sebenarnya bertiga, saat bertiga sebenarnya berempat, dan

${ }^{1}$ Jefri Al-Bukhori, Sekuntum Mawar untuk Remaja (Jakarta: Pustaka AlMawardi, 2006), 6 . 
seterusnya. Sebagaimana firman Allah yang artinya: "Tidakkah kamu perhatikan, bahwa sesungguhnya Allah mengetahui apa yang ada di langit dan apa yang ada di bumi? Tiada pembicaraan rahasia antara tiga orang, melainkan Dia-lah yang keempatnya. Dan tiada (pembicaraan antara) lima orang, melainkan Dia-lah yang keenamnya. Dan tiada (pula) pembicaraan antara (jumlah) yang kurang dari itu atau lebih banyak, melainkan Dia ada bersama mereka di manapun mereka berada. Kemudian Dia akan memberitakan kepada mereka pada hari kiamat apa yang telah mereka kerjakan. ${ }^{2}$ Sesungguhnya Allah Maha Mengetahui segala sesuatu". (QS. Al-Mujadilah: 7). Menurut Jefri al-Bukhari, hilangnya perasaan "merasa diawasi" inilah salah satu yang menyebabkan remaja sangat mudah melakukan perzinahan. Padahal tidak ada ruang di dunia ini yang terlepas dari pengawasan Allah SWT. Allah Maha Tahu dan Allah tidak pernah tidur ataupun lengah dalam mengawasi apa yang terjadi pada alam semesta ini. Karena itu, silakan berzina asal Allah tidak tahu. ${ }^{3}$

\section{Biograii Singkat}

Ustadz Jefri al-Bukhori lahir di Jakarta, 12 April 1973, yang akrab dipanggil "Uje". Ayahnya bernama H. Ismail Modal (alm) dan ibunya Ustz Dra. Hj. Tatu Mulyana. Dia anak ketiga dari lima bersaudara. Kakak pertamanya bernama Ustd H. Abdullah Riyad (almarhum), kakak keduanya bernama Ustd H. Aswan Faisal. Adik pertamanya adalah $H$. Decky Fajar, dan adiknya yang kedua bernama Ustd H. Nona.

Pada tanggal 7 September 1999 menikah dengan Pipik Dian Irawati. Dari pernikahannya itu, ia dikarunia dua orang anak yang bernama Adiba Khanza Az-Zahra dan Mohammad Abizar Al-Ghifari. Sejak kecil ia sudah belajar Al-Qur'an. Tidak mengherankan ketika duduk di bangku SD, ia telah memperoleh beberapa prestasi di dalam MTQ (Musabaqah Tilawatil Qur'an). Meskipun demikian,

\footnotetext{
${ }^{2}$ Ibid, 7.

${ }^{3}$ Ibid, 7.
} 
sebenarnya ia pernah memiliki dua sisi kepribadian yang berbeda. Di satu sisi, ia adalah seorang anak yang rajin mengaji, di sisi lain seorang pemabuk dan pecandu narkoba yang menyukai kehidupan malam. ${ }^{4}$ Kemudian tahun 1991, ia menjadi anggota dancer salah satu club malam. Pernah juga bermain di dalam sebuah sinetron (Sayap Patah) di stasiun TVRI; yang membawanya terpilih menjadi aktor terbaik di dalam sinetron tersebut. Pengalaman baiknya menjadi muslim yang shaleh terjadi ketika diajak umroh oleh ibu dan kakaknya. Setelah ia bertobat, ia diminta untuk memberikan dakwahdakwah di daerah Jakarta oleh ustd Abdulah Riyad (kakaknya), yang kebetulan waktu itu dipercaya MUIS (Majelis Ugame Islam Singapore) untuk menjadi Imam besar di Masjid Haji Mohammad Soleh. Dari dakwah-dakwahnya itu, akhirnya ia dikenal oleh kalangan luas. la sering disebut sebagai "Ustadz Gaul" karena sering menggunakan bahasa-bahasa gaul untuk menyapa anak muda, seperti halo choi, hallo friend, dan sebagainya. la pandai melantunkan ayatayat Al-Qur'an serta membuat contoh-contoh kisah menarik yang actual bagi kaum muda.

Meskipun tidak sempat menyelesaikan pendidikan perguruan tingginya, ustadz muda yang sedang naik daun ini tidak pernah berhenti "memperkaya diri" dengan ilmu-ilmu agama, karena baginya belajar adalah sepanjang hayat masih dikandung badan. Bakat sebagai penceramah mengalir deras dari ibunya ustazah $\mathrm{Hj}$. Tatu Mulyana Ismail. Karenanya ustadz muda yang sempat mencicipi 'nikmat semu' dunia narkoba ini mencurahkan sebagian besar waktunya untuk aktivitas dakwah, dalam beberapa tahun belakangan ini. Tidak hanya menyampaikan ceramah di berbagai majelis ta'lim, ia juga aktif menyampaikan materi dakwah di berbagai stasiun TV swasta, seperti ANTV, TPI, RCTI, TRANSTV, LATIVI, dan lain-lain. ${ }^{5}$ Suami dari Pipik Dian Irawati ini lebih memfokuskan bidikan dakwahnya untuk kalangan remaja. Karena dalam pandangan ayah dari Adiba Khanza

\footnotetext{
${ }^{4}$ http://www.Ust.Jefri.com.my

${ }^{5} \mathrm{http}: / /$ www.Ust.Jefri.com.my
} 
az-Zahra dan Mohammad Abidzar al-Ghifari ini, remaja adalah generasi masa depan yang sangat berperan dalam mewujudkan maju dan mundurnya bangsa ini. ${ }^{6}$

Pendidikan Jefry di mulai dengan mengikuti sekolah dasar. Ketika ia duduk di bangku SD, ia telah memperoleh beberapa prestasi di dalam MTQ (Musabaqah Tilawatil Qur'an). Pendidikan selanjutnya adalah Sekolah Menengah Atas, sambil mondok di beberapa pesantren. Ia pernah pesantren di Santi Asromo Majalengka yang dikelola oleh K.H. Abdul Khaer, cucu K.H. Abdul Halim (Pendiri Santi Asromo) (Jawa Barat), Babakan Ciwaringin Cirebon yang diasuh K.H. Fuad Amin, Pesantren Cipari Garut yang dikelola K.H. Bunyamin Syamuddin (alumnus alAzhar).

Puncak karir sang ustadz kondang ini memang cukup luar biasa. Dalam waktu tidak terlalu lama, ustadz bernama lengkap Jeffi Al Buchori telah menghiasi kaca televisi. Modal ini telah meluncurkan album berisi lagu-lagu religius yang diberi tajuk Lahir Kembali. Sebelumnya, ia juga meluncurkan paket album. Kali ini memang bukan berisi lagu-lagu dari suaranya yang merdu, melainkan berisi kisah perjalanan hidupnya yang sungguh dahsyat, penuh gejolak, dan tikungan tajam, serta proses pergulatan yang luar biasa dialami sampai menemukan kembali kehidupan yang tenang dan menenteramkan. Kisah hidupnya itu dikemas dalam paket Perjalanan Hidup Jeffry Al Buchori, baik berupa kaset, CD, maupun VCD. Masih ditambah sebuah VCD berupa tuntunan shalat bagi para pemula. Sebelumnya memang sudah banyak yang memintanya untuk menyinetronkan kisah hidupnya, tapi selama itu pula ia selalu menolak. Setelah ada ajakan dari Akurama Record, baru tertarik untuk merekam perjalanan hidupnya. Ia berharap bahwa dengan mengungkap kisah perjalanan hidupnya bisa menjadi madrasah, bukan hanya untuk dirinya, tetapi juga untuk mereka yang memang membeli kaset atau CD tersebut bagi yang ingin mengetahui kisah hidupnya," tutur Jeffry. la sendiri mengaku,

${ }^{6}$ http://www.Ust.Jefri.com.my 
sebetulnya tidak ingin lagi bercerita mengenai masa lalunya. "Maklum, sangat kelam. Tapi kalau memang ada gunanya bagi pembaca, ia tidak keberatan membaginya. Sekali lagi, semoga bisa menjadi madrasah bagi siapa pun, demikian tutur ustadz Jefry. Bagi sang ustadz, masa lalunya itu adalah madrasah baginya," tutur bapak dua anak itu. Jeffry lalu bercerita panjang lebar mengenai masa lalunya dalam kaset atau VCD tersebut. Beberapa karya tulis yang dipublikasikan di antaranya: Remaja Mencari Tuhan; Senandung Cinta; Panduan Menjadi Remaja yang Berbudi dan Berprestasi; Ada Apa dengan Wanita; Sekuntum Mawar Untuk Remaja.

Di antara sekian banyak pesan dakwahnya, maka pesan dakwah tentang generasi rabbani menjadi obyek penelitian ini. Dalam pandangan Jefri bahwa generasi rabbani yaitu generasi berketuhanan dan beriman yang dalam kehidupannya 1) mampu menjaga kemaluan; 2) bersikap tawakkal; 3) sabar; 4) berpikir positif. Penegasan ini ia sampaikan dalam ceramahnya di TV One didukung hasil wawancara.

\section{Mampu Menjaga Kemaluan (Kehormatan Diri)}

Suami dari Pipik Dian Irawati ini lebih memfokuskan bidikan dakwahnya untuk kalangan remaja. Karena dalam pandangan ayah dari Adiba Khanza az-Zahra dan Mohammad Abidzar al-Ghifari ini, remaja adalah generasi masa depan yang sangat berperan dalam mewujudkan maju dan mundurnya bangsa ini. Karena itu tidak heran jika dalam dakwahnya lebih banyak mengemukakan persoalan pergaulan remaja yang cenderung mengarah pada seks bebas, hal itu dapat disimak antara lain dalam pesan dakwahnya yang berjudul "Generasi Rabbani"Menurut Jefr al-Bukhari salah satu perkembangan baru pada usia remaja yang perlu diperhatikan adalah mulai timbulnya rasa senang atau ketertarikan pada lawan jenis. Bahkan rasa ketertarikan itu tidak sebatas senang memandang atau senang bercengkerama dengan lawan jenis melainkan juga, seiring pertumbuhan fisik yang mulai sempurna dan organ-organ seks mulai berfungsi, timbul keinginan pada remaja untuk melepaskan 
hasrat seksual. ${ }^{7}$ Berkait dengan organ seks yang mulai berfungsi dan keinginan untuk melepaskan hasrat seksnya, remaja berada pada persimpangan jalan yang berbahaya. Jika remaja tidak dapat mengendalikan emosinya, ia akan terjebakpada penyaluran hasrat seks secara tidak benar. Akibatnya di samping ia melakukan pelanggaran norma-norma agama dan etika, ia juga menderita secara kejiwaan, bahkanada sebagian harus meninggalkan bangku sekolah. Pada kasus yang terakhir ini, tentu sangat merugikan masa depannya. Namun demikian menurut Jefri al-Bukhari, fenomena penyaluran hasrat seksual secara bebas di kalangan remaja disinyalir sangat besar.

Hal ini sebagaimana laporan dari berbagai lembaga survei independen atau beberapa kasus yang dapat disaksikan langsung. Misalnya hasil polling yang dilakukan oleh "Sahabat Anak Remaja (Sahara) Indonesia Foundation" menghasilkan sedikitnya 38.288 remaja di Kabupaten Bandung diduga pernah berhubungan intim di luar nikah atau melakukan seks bebas. Berdasarkan hasil polling lewat telefon sebetulnya $20 \%$ dari 1.000 remaja pernah melakukan seks bebas. Hasil itu terjadi pada remaja di daerah perkotaan seperti Soreang, Banjaran dan lain-lain. Setelah dikaitkan dengan kenyataan dan bahkan banyak remaja yang tinggal di pedesaan diperkirakan 5\% sampai $7 \%$ remaja di Kab. Bandung telah melakukan seks bebas. Jumlah remaja di Kab. Bandung sebanyak 765.762, jadi remaja yang melakukan seks bebas antara 38.288 hingga 53.603 orang. Dari hasil polling juga diketahui, dari sekitar 200 remaja yang melakukan seks bebas $50 \%$ atau 100 remaja itu hamil. ${ }^{8}$ Kota Yogya juga pernah digegerkan hasil penelitian seks pranikah suatu lembaga di kota itu yang menyatakan 97,05\% mahasiswi dari 1.660 responden telah melakukan hubungan seks pranikah. Kemudian penelitian Pusat Penelitian Kependudukan, UGM (1991) pada remaja berumur 14-24 tahun di Manado, mengungkapkan laki-laki 151 orang dan 146 orang

\footnotetext{
${ }^{7} \mathrm{CD} / \mathrm{DVD}$ dakwah Ustadz Jefri Al-Bukhori

${ }^{8} \mathrm{CD} / \mathrm{DVD}$ dakwah Ustadz Jefri Al-Bukhori
} 
perempuan terbukti $26,6 \%$ melakukan perilaku seks pranikah. Penelitian lain dilakukan oleh Lembaga Konselor Sahabat Remaja di Medan yang melaporkan data tahun 1990 ada 80 remaja usia 14-24 tahun hamil sebelum menikah. Hasil penelitian ini sangat mengejutkan, kenapa remaja yang hidup di negeri yang sangat agamis berperilaku seperti di negeri tanpa agama? Apa sesungguhnya yang terjadi pada remaja? Padahal perzinahan merupakan perbuatan yang sangat keji dan harus dihindari oleh setiap muslim. ${ }^{9}$ sebagaimana firman Allah:

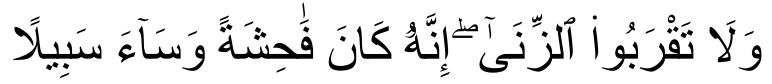

Artinya:

"Dan janganlah kamu mendekati zina; sesungguhnya zina itu adalah suatu perbuatan yang keji dan suatu jalan yang buruk." (OS. Al- Isra': 32).

Larangan zina dalam ayat di atas sangat tegas, bahkan Allah melarangnya dengan kalimat "janganlah kalian dekati zina". Larangan ini menurut Jefri al-Bukhari mengandung arti, zina merupakan perbuatan yang sangat keji dan akan mendatangkan madharat karena itu harus dijauhi sejauh-jauhnya, tidak saja zinanya tetapi juga semua perbuatan yang mengarah kepada zina. Sangat masuk akal, apabila larangan zina dengan redaksi seperti itu, karena zina merupakan perbuatan yang sangat sulit dijauhi apabila seseorang memiliki kesempatan untuk melakukannya. Mungkin orang bisa kuat untuk menahan dirinya agar tidak mencuri, tidakmenzalimi orang lain, tidak berkata dusta dan lain sebagainya. Tetapi untuk tidak berzina manakala ia memiliki kesempatan adalah perjuangan yang sangat keras. Karena itu, banyak orang-orang besar yang jatuh harga dirinya disebabkan melakukan zina, padahal mereka dikenal masyarakat sebagai orang yang sudah bagus keimanannya bahkan rukun Islam yang lima sudah dijalani semua. Demikian banyak kalangan remaja yang semestinya masih menekuni bangku sekolah,

\footnotetext{
${ }^{9}$ Jefri Al-Bukhori, Sekuntum Mawar untuk Remaja, 3.
} 
gagal di tengah jalan akibat perzinahan. ${ }^{10}$

Hal ini terjadi karena zina sangat berkait dengan kebutuhan manusia yang paling mendasar yang sudah berkolaborasi sangat kuat dengan nafsu manusia. Padahal nafsu senantiasa mengajak manusia kepada kejelekan. Allah SWT berfirman:

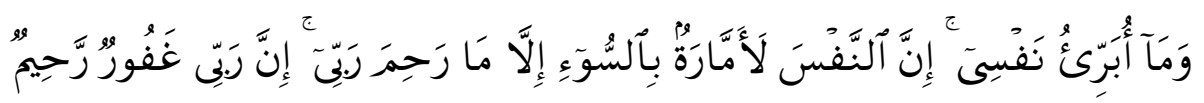

\section{Artinya:}

"Dan aku tidak membebaskan diriku (dari kesalahan), karena sesungguhnya nafsu itu selalu menyuruh kepada kejahatan, kecuali nafsu yang diberi rahmat oleh Tuhanku. Sesungguhnya Tuhanku Maha Pengampun lagi Maha Penyayang." (OS. Yusuf: 53)

Karena itu, Allah melarang zina tidak langsung pada perbuatannya, tetapi justru melarang semua perbuatan yang dapat menyebabkan zina. Secara logika dapat dikatakan jika perbuatan yang dapat mengarahkan kepada zina saja dilarang apalagi perbuatan zinanya. Maka sangat tidak berdasar orang-orang yang mengatakan, "Yang dilarang bukan zinanya, tetapi perbuatan yang mendahului zina." Ungkapan ini diucapkan oleh orang-orang yang mencari celah untuk melakukan perzinahan, hal tersebut dapat dilihat dalam bukunya. ${ }^{11}$ Menurut Jefri al-Bukhari, Islam tidak hanya melarang perzinahan, tetapi juga memberikan sangsi keras terhadap para pezina. ${ }^{12}$ Sebagaimana disebutkan dalam firman Allah berikut:

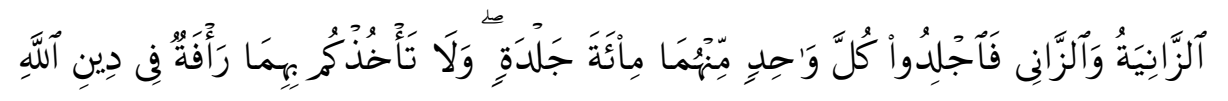

\footnotetext{
${ }^{10}$ Ibid, 4.

${ }^{11}$ Ibid, 4.

${ }^{12}$ Ibid, 5 .
} 


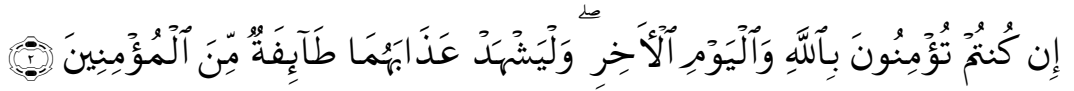

\section{Artinya:}

"Perempuan yang berzina dan laki-laki yang berzina, maka deralah tiap-tiap seorang dari keduanya seratus kali dera, dan janganlah belas kasihan kepada keduanya mencegah kamu untuk (menjalankan) agama Allah, jika kamu beriman kepada Allah, dan ban akhirat, dan hendaklah (pelaksanaan) hukuman mereka disaksikan oleh sekumpulan dari orang-orang yang beriman.” (OS. An-Nur: 2).

Dalam ayat tersebut disebutkan bahwa hukuman bagi pezina baik laki-laki maupun perempuan adalah dijilid 100 kali di hadapan orang banyak. Dalam suatu hadis ditambahkan selain dijilid 100 kali, pezina juga setelah dijilid harus diasingkan selama 1 tahun. Bahkan bagi pezina yang sudah menikah hukumannya dirajam, yaitu setengah badannya dipendam lalu dilempari batu sampai meninggal. Demikian tegas larangan dan ancaman terhadap para pelaku zina dalam Islam. Namun sayangnya masih banyak kalangan remaja yang tidak mengindahkannya. Padahal akibat perzinahan sangat merugikan baik di dunia maupun di akhirat. ${ }^{13}$

Allah telah menjadikan rasa cinta dalam diri manusia baik pada laki-laki maupun perempuan. Dengan adanya rasa cinta, manusia bisa hidup berpasang-pasangan. Adanya pernikahan tentu harus didahului rasa cinta. Seandainya tidak ada cinta, pasti tidak ada orang yang mau membangun rumah tangga. Seperti halnya hewan, mereka memiliki instink seksualitas tetapi tidak memiliki rasa cinta, sehingga setiap kali bisa berganti pasangan. Hewan tidak membangun rumah tangga. Menyatakan cinta sebagai kejujuran hati tidak bertentangan dengan syariat Islam. Karena tidak ada satu pun ayat atau hadis yang secara eksplisit atau implisit melarangnya.

\footnotetext{
${ }^{13}$ Ibid, 6 .
} 
Islam hanya memberikan batasan-batasan antara yang boleh dan yang tidak boleh dalam hubungan laki-laki dan perempuan yang bukan suami istri. ${ }^{14}$ Menurut Jefri al-Bukhari, diantara batasan-batasan tersebut ialah:

1 Tidak melakukan perbuatan yang dapat mengarahkan kepada zina. Allah SWT berfirman, "Dan janganlah kamu mendekati zina; sesungguhnya zina itu adalah suatu perbuatan yang keji dan suatu jalan yang buruk." (QS. Al-Isra: 32) Maksud ayat ini, janganlah kamu melakukan perbuatan-perbuatan yang bisa menjerumuskan kamu pada perbuatan zina. Di antara perbuatan tersebut seperti berdua-duaan dengan lawan jenis di tempat yang sepi, bersentuhan termasuk bergandengan tangan, berciuman, dan lain sebagainya.

2 Tidak menyentuh perempuan yang bukan mahramnya. Rasulullah SAW bersabda, "Lebih baik memegang besi yang panas daripada memegang atau meraba perempuan yang bukan istrinya (kalau ia tahu akan berat siksaanya)."

3 Tidak berduaan dengan lawan jenis yang bukan mahramnya. Dilarang laki dan perempuan yang bukan mahram untuk berduaduan. Nabi S.A.W. bersabda, "Barangsiapa beriman kepada Allah dan hari akhir, maka jangan sekali-kali dia bersendirian dengan seorang perempuan yang tidak bersama mahramnya, karena yang ketiganya adalah setan." (HR. Ahmad) Nabi juga bersabda, "Jangan sekali-kali salah seorang di antaramu menyendiri dengan seorang perempuan, kecuali bersama mahramnya". Dalam hal ini termasuk juga dengan ipar. Ada seorang Anshar bertanya kepada Nabi, "Bagaimana pendapatmu tentang ipar?" Nabi menjawab, "Bersendirian dengan ipar sama dengan menjumpai mati." (HR. Bukhari)

4 Harus menjaga mata atau pandangan. Sebab mata itu kuncinya hati, dan pandangan itu pengutus fitnah yang sering membawa kepada perbuatan zina. Oleh karena itu Allah berfirman, "Katakanlah kepada laki-laki mukmin hendaklah mereka

\footnotetext{
${ }^{14}$ Ibid, 14
} 
memalingkan pandangan mereka (dari yang haram) dan menjaga kehormatan mereka....Dan katakanlah kepada kaum wanita hendaklah mereka meredupkan mata mereka dari yang haram dan menjaga kehormatan mereka.." (OS. An-Nur: 30-31). Yang dimaksudkan menundukkan pandangan yaitu menjaga pandangan, tidak melepaskan pandangan begitu saja apalagi memandangi lawan jenis penuh dengan gelora nafsu. Kita hanya dibolehkan memandang lawan jenis seperlunya saja, tidak boleh berlebihan. Rasulullah bersabda, "Hai Ali! Jangan sampai pandangan yang satu mengikuti pandangan lainnya. Kamu hanya boleh pada pandangan pertama, adapun yang berikutnya tidak boleh." (HR. Abu Daud dan Tirmidzi). Pandangan liar kepada lawan jenis dianggap Rasulullah sebagai perbuatan zina, "Dua mata itu bisa berzina, dan berzinanya itu melihat." (HR.Bukhari) Dinamakan berzina karena dalam memandangnya mendatangkan kesenangan seksualitas dengan jalan yang tidak dibenarkan syari'ah.

5 Menutup aurat. Menurut Jefri al-Bukhari, diwajibkan kepada kaum wanita untuk menjaga aurat dan dilarang memakai pakaian yang mempertontonkan bentuk tubuhnya, kecuali untuk suaminya. Dalam Hadits dikatakan bahwa wanita yang keluar rumah dengan berpakaian yang mempertontonkan lekuk tubuh, memakai minyak wangi yang baunya semerbak, memakai make up dan sebagainya, setiap langkahnya dikutuk oleh para Malaikat, dan setiap laki-laki yang memandangnya sama dengan berzina dengannya. Di hari kiamat nanti perempuan seperti itu tidak akan mencium baunya surga (apa lagi masuk surga). Selagi batasan di atas tidak dilanggar, maka pacaran hukumnya boleh. Tetapi persoalanny mungkinkah pacaran tanpa berpandang-pandangan, berpegangan, bercanda ria, berciuman dan lain sebagainya? Kalau mungkin silakan berpacaran, tetapi kalau tidak mungkin maka jangan sekali-kali berpacaran karena azab yang pedih siap menanti anda. Salah satu pembicaraan yang tak kalah pentingnya di kalangan remaja adalah 
persoalan romantis. Kata-kata romantis sungguhpun milik semua kalangan, tetapi kesannya hanya miliki para remaja. Karena, hampir pada setiap pembicaraan mereka tentang percintaan, persoalan romantic tidak pernah lepas. Bagi mereka, percintaan yang sukses adalah percintaan yang diiringin romantisme. Semua remaja berharap percintaan mereka diiringi romantisme. ${ }^{15}$

Romantis pada umumnya dipahami sebagai suasana yang penuh kemesraan. Dalam hubungan antara dua insan berlainan jenis, maka romantis berarti hubungan yang mesra. Di mata remaja, kemesraan berarti keterpaduan emosional dengan hati sang kekasih yang diwujudkan dengan berbagai ekspresi. Biasa romantisme diwujudkan dalam kerinduan yang amat sangat, sanjungan-sanjungan, sikap sangat memperhatikan, helaian mesra, ciuman, dan bahkan ada yang sampai melakukan hubungan laksana suami istri. Remaja biasanya bangga jika pacarannya bisa mencapai romantisme. Bahkan mereka biasanya mengecam temannya yang tidak bisa romantis dalam berpacaran dengan mengatakan, "Payah luh pacarannya kagak romantis, lihat gue dong!" Atau, "Lu pacaran apa diskusi!" Dan berbagai ucapan lainnya. Seakan-akan kalau pacaran tidak romantis itu kuno, ndeso dan ketinggalan zaman. Karena pandangan ini, para remaja berusaha semaksimal mungkin mencapai romantisme dalam berpacaran, sampai-sampai banyak terjadi hamil di luar nikah dan aborsi. ${ }^{16}$

Benarkah demikian? Tentu tidak, karena romantisme semacam itu hanya milik orang-orang yang sudah menjalin hubungan suami istri. Bagi remaja, romantisme haruslah dipahami sebagai suasana yang saling memberikan kontribusi positif antara kedua belah pihak. Jika seorang remaja terlanjur sudah memiliki seseorang yang disebutnya sebagai "kekasih atau pacar", maka jadikanlah sebagai teman yang senantiasa memberikan motivasi dalam mengejar prestasi dan kemajuan. Hindari banyak pertemuan dengan sang

\footnotetext{
${ }^{15}$ Ibid, 17.

${ }^{16} \mathrm{Ibid}, 18$.
} 
kekasih apalagi berdua-duaan. Kekasih atau pacar bagi remaja sebenarnya tidak perlu, karena justru lebih banyak mendatangkan madharat (kerugian). Banyak remaja stres karena cinta ditolak atau diputus, bahkan sampai ada yang depresi dan bunuh diri. Karena kekasih pula banyak remaja yang melalaikan tugas belajarnya. Mereka terpana dengan kenikmatan berpacaran dan indahnya bercinta. Sehingga banyak remaja yang gagal di tengah jalan akibat percintaan. Perjalanan yang masih panjang disudahinya hanya disebabkan keterpanaan dengan indahnya asmara. ${ }^{17}$

Mereka menderita kerugian dunia, padahal sebenarnya mereka mempunyai peluang yang besar untuk memperoleh keberuntungan dunia. Mereka juga mengalami kerugian akhirat, karena telah terjerumus dalam kemaksiatan. Pujaannya terhadap sang kekasih telah membuatnya lupa terhadap Kekasih yang sesungguhnya. Kekasih yang telah memberikan kepadanya segala-galanya. Menurut Jefri alBukhari, kalau kita lebih memilih kekasih dunia, dan melupakan Kekasih yang sesungguhnya berarti kita telah membeli dunia dengan akhirat. Padahal dunia harganya sangat murah, sedangkan akhirat sangat mahal. Kita telah menjual akhirat kita dengan harga yang sangat murah. Tentu kita tidak akan beruntung. ${ }^{18}$ Allah SWT berfirman:

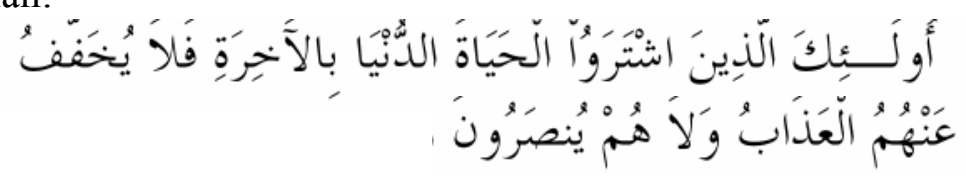

Artinya:

Itulah orang-orang yang membeli kehidupan dunia dengan (kehidupan) akhirat, maka tidak akan diringankan siksa mereka dan mereka tidak akan ditolong. (QS. al-Baqarah: 8)

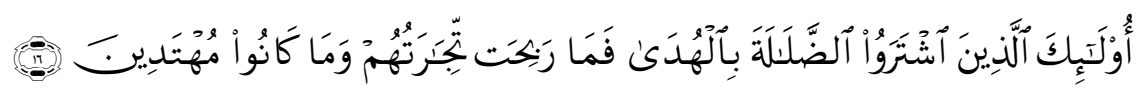

\footnotetext{
${ }^{17}$ Ibid, 18.

${ }^{18}$ Ibid, 19.
} 


\section{Artinya:}

Mereka itulah orang yang membeli kesesatan dengan petunjuk, maka tidaklah beruntung perniagaan mereka dan tidaklah mereka mendapat petunjuk. (OS. Al-Baqarah: 16).

Jika seorang remaja tidak ingin mengalami kerugian, maka seharusnya tinggalkan saja kekasih dunianya dan lemparkan jauhjauh namanya pacaran, lalu berkonsentrasilah menata masa depan dengan belajar giat dan mengembangkan potensi diri. Sebab masa depan lebih baik dari masa kini. Jika masa kini kita bahagia, tapi di masa yang akan datang kita bersedih berarti kita adalah orang yang merugi. ${ }^{19}$ Allah berfirman: Artinya: "Dan sesungguhnya akhirat itu lebih baik bagimu dari permulaan." (OS. Adh-Dhuha: 4). Jadi sebagai remaja Islam, menurut Jefri al-Bukhari, harus lebih mementingkan masa depan, karena masa depan lebih baik dari sekarang. Baik masa depan di dunia maupun masa depan di akhirat. Agar bisa selamat dari jebakan pacar atau kekasih dunia, maka remaja harus mencari kekasih yang lain, kekasih yang lebih memberikan kebahagiaan hakiki. Yaitu kekasih yang telah menciptakan manusia, menghidupkannya, dan melimpahkan rezekiNya kepada manusia. Dia Allah Swt Tuhan semesta alam. Menurut Jefri al-Bukhari, seorang remaja tidak semestinya terlalu terpana dengan keindahan dunia. Justru pada usia ini seharusnya remaja mendekatkan diri kepada sang Khalik, Tuhan yang telah menciptakan dan mengatur masa depannya. Karena jika remaja pada usianya sudah mendekatkan diri kepada Allah, segenap permintaannya akan dikabulkan dan ia akan memiliki masa depan yang gemilang. Ketika seorang remaja sudah mendekatkan diri kepada Allah, maka keinginan-keinginan untuk mencari kekasih dunia dapat ditahan, sehingga ia dapat berkonsentrasi terhadap pelajaran sekolah serta kegiatan-kegiatan positif lainnya. Saat teman-temannya berbicara mengenai romantisme berpacaran dengan kekasih dunia, ia

\footnotetext{
${ }^{19}$ Ibid, 20.
} 
pun tidak kalah dapat bercerita tentang romantismenya bercinta dengan Kekasih hakiki Allah SWT. ${ }^{20}$

Menurut Jefri al-Bukhari, barangkali ada di antara kita yang meragukan, apakah mungkin bercinta dengan kekasih yang tidak kasat mata, yang tidak bersama kita dan yang tidak bisa kita kunjungi? Sangat mungkin, karena justru bercinta dengan Kekasih hakiki, kita akan senantiasa melihat-Nya dengan menyaksikan segenap ciptaanNya yang agung, kita juga akan senantiasa bersama- Nya, bahkan setiap saat kita bisa datang kepada-Nya tanpa melalui perantara dan izin siapapun. ${ }^{21}$

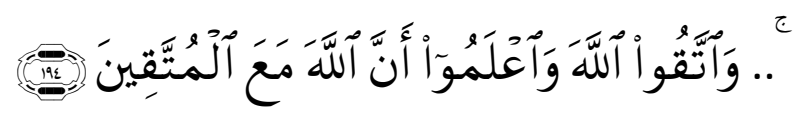

\section{Artinya:}

“......Bertakwalah kepada Allah dan ketahuilah, bahwa Allah beserta orang-orang yang bertakwa. (OS. Al-Baqarah: 194).

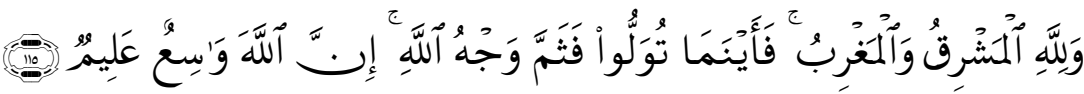

\section{Artinya:}

Dan kepunyaan Allah-lah timur dan barat, maka ke manapun kamu menghadap di situlah wajah Allah. Sesungguhnya Allah Maha Luas (rahmat-Nya) lagi Maha Mengetahui. (OS. Al-Baqarah: 115).

\section{Bersikap Tawakkal}

Seorang yang bertawakal, hatinya menjadi tenteram, karena yakin akan keadilan dan rahmat-Nya, oleh karena itu, Islam menetapkan iman harus diikuti dengan sifat tawakal

\footnotetext{
${ }^{20}$ Ibid, 21.

${ }^{21}$ Ibid, 21.
} 
sebagaimana Firman Allah:

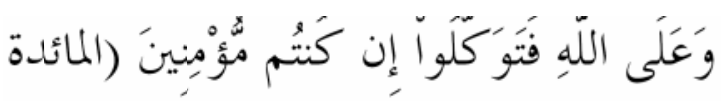

\section{Artinya:}

Dan hanya kepada Allahlah hendaknya kamu bertawakal, jika kamu benar-benar orang yang beriman (QS. al-Maidah: 23)

Menurut ajaran Islam, tawakal merupakan landasan atau tumpuan terakhir dalam sesuatu usaha atau perjuangan, manusia harus berserah diri kepada Allah setelah menjalankan ikhtiar. Meskipun tawakal diartikan sebagai penyerahan diri dan ikhtiar sepenuhnya kepada Allah SWT, namun tidak berarti orang yang bertawakal harus meninggalkan semua usaha dan ikhtiar. Keliru jika tawakal diartikan sebagai sikap pasrah kepada Allah SWT tanpa diiringi dengan usaha maksimal. Tawakal dalam pengertian di atas meliputi paling tidak dua unsur yaitu berserah pada Allah Swt dan ikhtiar, inilah tawakal yang menjadi das sollen (suatu keharusan). Dalam alQur'an, Allah Swt menegaskan:

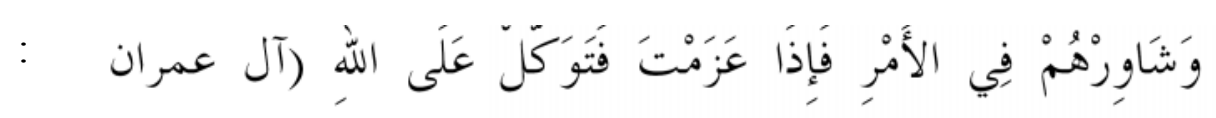

Artinya:

Dan bermusyawarahlah dengan mereka pada setiap urusan, apabila engkau telah berketetapan hati, maka menyerah dirilah engkau kepada Allah. (Q,S. Ali-Imran/3:159).

Orang yang bertawakal kepada Allah SWT tidak akan berkeluh kesah dan gelisah. la akan selalu berada dalam ketenangan, ketenteraman, dan kegembiraan. Jika memperoleh nikmat dan karunia dari Allah SWT, ia akan bersyukur, dan jika tidak atau kemudian misalnya mendapat musibah, ia akan bersabar. la menyerahkan semua keputusan, bahkan dirinya sendiri kepada Allah SWT. Penyerahan diri itu dilakukan dengan sungguh-sungguh 
dan semata-mata karena Allah Swt. Keyakinan utama yang mendasari tawakal adalah keyakinan sepenuhnya akan kekuasaan dan kemahabesaran Allah SWT. Karena itulah tawakal merupakan bukti nyata dari tauhid. Di dalam batin orang yang bertawakal tertanam iman yang kuat bahwa segala sesuatu terletak di tangan Allah Swt dan berlaku atas ketentuan-Nya. Tidak seorang pun dapat berbuat dan menghasilkan sesuatu tanpa izin dan kehendak Allah SWT, baik berupa hal-hal yang memberikan manfaat atau mudarat dan menggembirakan atau mengecewakan. Menurut para ulama kalam dan fikih, hikmah dan keutamaan tawakal antara lain membuat seseorang penuh percaya diri, memiliki keberanian dalam menghadapi setiap persoalan, memiliki ketenangan dan ketenteraman jiwa, dekat dengan Allah SWT dan menjadi kekasih-Nya, dipelihara, ditolong, dan dilindungi Allah SWT, diberikan rezeki yang cukup, dan selalu berbakti dan taat kepada Allah SWT.

Orang yang tawakal akan mampu menerima dengan sabar segala macam cobaan dan musibah. Berbagai musibah dan malapetaka yang melanda Indonesia telah dirasakan masyarakat. Bagi orang yang tawakal maka ia rela menerima kenyataan pahit, sementara yang menolak dan atau tidak tawakal, ia gelisah dan protes dengan nasibnya yang kurang baik. Realita fenomena di masyarakat terjadi suatu kesenjangan antara teori yang mengharuskan ikhtiar maksimal dengan pasrah diri sepenuhnya tanpa usaha. Dengan kata lain kenyataan menunjukkan bahwa persepsi yang berkembang di sebagian masyarakat yaitu tawakal merupakan bentuk pasrah diri pada Allah Swt namun tanpa ikhtiar. Persepsi yang keliru ini mengakibatkan umat Islam berada dalam kemunduran dan tidak mampu bersaing dengan dinamika zaman. Kenyataan ini dapat dijumpai dalam kehidupan se hari-hari.

\section{Bersikap Sabar}

Setiap manusia dalam kehidupannya menghendaki dapat meraih sukses, untuk meraih sukses tidak cukup hanya mengandalkan kecerdasan intelektual. Dengan kata lain, dibutuhkan 
pula kecerdasan lain yang dapat menopang keberhasilannya yaitu kecerdasan emosional. Kecerdasan emosional diukur dari kemampuan mengendalikan emosi dan menahan diri. Dalam Islam kemampuan mengendalikan emosi dan menahan diri disebut sabar. Orang yang paling sabar adalah orang yang paling tinggi kecerdasan emosionalnya. Ia biasanya tabah menghadapi kesulitan. Ketika belajar biasanya orang ini tekun. Ia biasanya berhasil mengatasi berbagai gangguan dan tidak memperturutkan emosinya, ia dapat mengendalikan emosinya. Allah SWT berfirman:

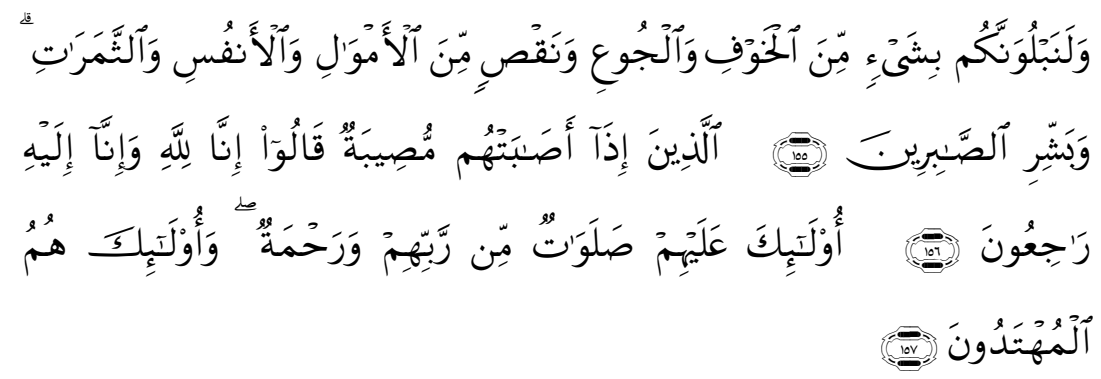

Artinya:

"Dan sungguh akan Kami berikan cobaan kepadamu, dengan sedikit ketakutan, kelaparan, kekurangan harta, jiwa dan buah- buahan. Dan berikanlah berita gembira kepadaorang-orang yang sabar. Yaitu orang-orang yang apabila ditimpa. musibah, mereka mengucapkan Inna lillahi wa inna ilaihi raji'un. Mereka itulah yang mendapat keberkatan yang sempurna dan rahmat dari Tuhan mereka, dan mereka itulah orang-orang yang mendapat petunjuk." (QS. Al-Baqarah 2: 155-157).

Kesabaran mengajari manusia ketekunan dalam bekerja serta mengerahkan kemampuan untuk merealisasikan tujuan-tujuan amaliah dan ilmiahnya. Sesungguhnya sebagian besar tujuan hidup manusia, baik di bidang kehidupan praksis misalnya sosial, ekonomi, dan politik maupun dalam bidang penelitian ilmiah, membutuhkan banyak waktu dan banyak kesungguhan. Oleh sebab itu, ketekunan dalam mencurahkan kesungguhan serta kesabaran 
dalam menghadapi kesulitan pekerjaan dan penelitian merupakan karakter penting untuk meraih kesuksesan dan mewujudkan tujuantujuan luhur. Kesabaran menuntut ketabahan dalam menghadapi sesuatu yang sulit, berat, dan pahit, yang harus diterima dan dihadapi dengan penuh tanggung jawab. Berdasar kesimpulan tersebut, para agamawan merumuskan pengertian sabar sebagai menahan diri atau membatasi jiwa dari keinginannya demi mencapai sesuatu yang baik atau lebih baik (luhur). Sabar artinya menahan diri dari rasa gelisah, cemas dan amarah; menahan lidah dari keluh kesah; menahan anggota tubuh dari kekacauan. Sabar adalah tabah hati tanpa mengeluh dalam menghadapi godaan dan rintangan dalam jangka waktu tertentu dalam rangka mencapai tujuan.

\section{Berpikir Positii}

Pikiran/berpikir positif adalah potensi dasar yang mendorong manusia untuk berbuat dan bekerja dengan menginvestasikan seluruh kemampuan kemanusiaannya. Berpikir positif akan membuat hidup seseorang menjadi lebih baik. Itulah pikiran yang membantu seseorang dalam mengembangkan akal, perasaan, dan perilakunya menjadi lebih baik. Itulah pikiran yang dapat menyingkap kekuatan tersembunyi pada manusia dan mengubah kehidupannya menjadi lebih berkualitas. Sebaliknya pikiran/berpikir negatif adalah sekumpulan pikiran salah yang menghambat langkah kita menuju kondisi yang lebih baik dan membuat perilaku kita tidak terarah. Pikiran negatif membuat kita menjadi manusia-manusia yang tidak mampu: tidak mampu karena lemah atau tidak mampu karena merasa tidak berhak untuk sukses. Berpikir positif adalah menggunakan kinerja otak kita untuk memikirkan hal-hal yang positif. Langkah ini tak ubahnya seperti "meng- install otak dengan file-file dan program-program yang positif. Ketika ini sudah menjadi sebuah kebiasaan maka dengan sendirinya otak akan menyuguhkan perintah, ide, dan renungan-renungan positif atas segala sendi kehidupan yang kita jalani.

Pikiran adalah keistimewaan yang dipakai manusia untuk 
memilih sesuatu dari beberapa alternatif dan menentukan pilihan pada hal yang menguntungkan masa depan diri dan keluarganya. Dalam buku What People Think Will be Acquired, adanya pemikiran pada manusia membuatnya mampu menentukan pilihan dalam hidup. Dalam ilmu psikologi sosial, para ilmuwan sepakat bahwa kemampuan berpikir yang ada pada manusia telah menjadikannya sebagai makhluk paling spesial. Kemampuan itu sebagai pembeda antara manusia dengan binatang, tumbuhan, dan benda mati. Kemampuan berpikir pula yang membuat seseorang bisa membedakan mana yang berguna atau merugikan dirinya, mana yang halal dan mana yang haram, dan mana yang mungkin dicapai dan mana pula yang tak mungkin diraihnya. Dengan adanya pikiran, manusia mampu memilih hal yang sesuai dengan dirinya dan memungkinkan baginya untuk diraih. Lalu, apa sesungguhnya yang dimaksud dengan hal-hal positif? Secara teoritis banyak definisi yang bisa diajukan sebagai konsep terkait hal positif. Namun, secara praktis, yang disebut dengan hal positif adalah setiap pemikiran, ide, sikap, tindakan atau perbuatan yang mampu mengarahkan dan mendekatkan diri kepada fitrah kemanusiaan kita yang suci. Melangkah lebih dekat menuju realitas tertinggi (Allah Swt) dengan amalan amalan yang bermanfaat baik untuk diri sendiri maupun orang lain. Dari sinilah terlihat jelas konsep kebermanfaatan manusia secara positif. Singkatnya, setiap yang bermanfaat merupakan perwujudan dari gerak ide maupun perbuatan positif.

Berpikir positif dengan sendirinya juga mengerdilkan untuk tidak menyebut membunuh potensi keburukan yang ditimbulkan oleh bisikan nafsu jahat manusia yang bisa menjurus pada fasad (kerusakan), baik dalam skala makro maupun mikro. Apa alasan yang mendasari bahwa berpikir positif sama halnya dengan "mengerdilkan" potensi kejahatan (negativisme) dalam diri maupun jiwa manusia? Hal ini karena menurut beragam kajian tentang kinerja otak manusia, salah satunya dikemukakan oleh Ibrahim Elfiky, bahwa otak manusia tidak bisa digunakan untuk memikirkan dua hal 
berlainan pada saat bersamaan. Jika seseorang memikirkan hal-hal positif maka dengan sendirinya otak akan mengunci "pintu" bagi masuknya ide atau; pikiran negatif. Masih dalam pengertian yang seirama, Allah Swt pun jauh-jauh hari telah memberitahukan kepada manusia bahwa Dia tidak pernah membuat dua ruang dalam satu hati. Artinya, sebagaimana kinerja otak, kinerja hati pun tidak jauh berbeda. Mana yang paling dominan di antara dua hal yang ada maka itulah yang akan menempati relung hati dan lorong otak seseorang. Oleh karenanya,dalam Islam dikenal sebuah istilah tazkiyatun nafsi (penyucian diri). Langkah ini dilakukan sebagai titik tolak seseorang menuju hidup yang suci dan bersih (positif). Segala hal yang negatif dikeluarkan dan dibuang terlebih dahulu sebelum menggantinya dengan yang positif. Mengapa? Karena sesungguhnya kebenaran tidak akan pernah bisa bercampur dengan kejahatan. Allah swt berfirman,

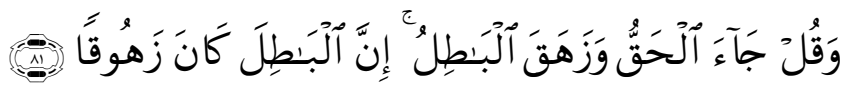

Artinya:

Dan katakanlah, kebenaran telah datang dan yang batil telah lenyap dan sesungguhnya yang batil itu telah lenyap. "(QS. Al-Isra' [17]: 81).

Dari ayat tersebut, apa yang bias dambil sebagai poin terpenting? Yaitu, untuk menghancurkan kebathilan (negativisme), manusia sebenarnya tidak perlu terlalu fokus pada kebatilan itu sendiri karena hanya akan menguras energi. Langkah tepat dan cerdas untuk mengantisipasinya adalah gunakan daya positif luar biasa yang dimiliki. Ingatlah, manusia oleh Allah dianugerahi kekuatan luar biasa yang konon menurut para pakar, kekuatan itu lebih canggih dari kinerja semesta. Kekuatan apakah yang dimaksud? Jawabnya adalah otak (akal pikiran). Bagaimana cara menuju pikiran dan hidup yang positif? Rasulullah saw menganjurkan agar seseorang melakukan keburukan, segeralah menggantinya dengan amalan yang baik lalu beristiqamahlah dalam kebaikan tersebut. Beliau saw 
bersabda, Dan ikutilah keburukan dengan kebaikan, mudah-mudahan yang baik itu akan menghapusnya dan pergaulilah manusia dengan akhlak terpuji."

\section{Penutup}

Pergaulan bebas antara remaja yang berlawanan jenis sangat memicu terjadinya perzinahan. Bagaimana tidak, jika mereka selalu dengan lawan jenisnya, terutama pada tempat tempat yang tidak ada pengawasan orang lain, tentu mereka akan melakukan perzinahan. Sebab saat itu gelora nafsunya muncul dan suasananya memungkinkan untuk melakukannya. Sementara mereka tidak memiliki pemikiran yang panjang serta tidak memiliki perasaan merasa diawasi. Karena itu, Allah melarang perbuatan yang dapat menyebabkan terjadinya zina. Pergaulan bebas adalah tangga yang akan mengantarkan kepada perzinahan. Menurut Jefri al-Bukhari, seks sebenarnya anugerah yang diberikan Allah pada makhluk-makhlukNya seperti binatang, tumbuh-tumbuhan dan khususnya manusia. Karena itu amat wajar kalau manusia memiliki gairah seksual dan ingin melampiaskan keinginan seksualnya. Allah SWT sendiri tidak pernah melarang manusia untuk melampiaskan keinginan seksualnya selama menempuh jalur yang dibenarkan, cara-cara yang benar dan pada saat yang tidak terlarang. Ketentuan ini diberlakukan untuk kepentingan manusia juga. Jalur yang dibenarkan Allah bagi manusia untuk melampiaskan keinginan seksnya itu adalah jalur pernikahan. Ini berarti orang yang belum menikah jangan coba-coba melampiaskan keinginan seksualnya. Tapi keinginan atau hawa nafsu itu tetap tidak boleh dibunuh, hanya harus dikendalikan agar manusia tidak dikendalikan oleh hawa nafsunya sendiri.

Khususnya bagi remaja, gairah seksual yang mulai tumbuh dalam dirinya harus dapat dikendalikan. Remaja harus mampu mendahulukan kepentingan yang lebih berjangka panjang. Yaitu mempersiapkan diri untuk menghadapi masa depan. Memang, Allah SWT telah mensyariatkan pernikahan sebagai jalan halal untuk melampiaskan hasrat seksual, namun bagi remaja sebaiknya tidak 
terburu-buru untuk melakukannya. Karena perkawinan tidak sekedar masalah seksualitas, tetapi juga pembinaan keluarga yang menyangkut penafkahan, pemeliharaan anak dan lain-lain (alBukhori, 2006: 10). Sementara kebanyakan remaja belum memiliki kemampuan untuk memberikan nafkah dan kedewasaan untuk membina keluarga. Karena itu, untuk mengatasi keinginan seksualitas yang mulai muncul pada remaja, sebaiknya remaja disibukkan dengan berbagai kegiatan yang menunjang masa depannya, seperti giat belajar, rajin mengikuti kegiatan keagamaan, berolah raga, bermain musik, mengikuti kursus-kursus, dan ain sebagainya. Dengan cara demikian seorang remaja akan mampu mengatasi gejolak seksualnya.

Menurut Jefri al-Bukhari, istilah pacaran tidak bisa lepas dari remaja, karena salah satu ciri remaja yang menonjol adalah adanya rasa senang kepada lawan jenis disertai keinginan untuk memiliki. Pada masa ini, seorang remaja biasanya mulai 'naksir' lawan jenisnya. Lalu berupaya melakuka pendekatan untuk mendapatkan kesempatan mengungkapkan isi hatinya. Setelah pendekatannya berhasil dan gayung bersambut, lalu keduanya mulai berpacaran. Pacaran dapat diartikan bermacam-macam, tetapi intinya adalah jalinan cinta antara seorang remaja dengan lawan jenisnya. Praktik pacaran juga bermacam-macam, ada yang sekedar berkirim surat, telepon, menjemput, mengantar atau menemani pergi ke suatu tempat, apel, sampai ada yang layaknya pasangan suami istri.

Menurut Jefri al-Bukhari, di kalangan remaja sekarang ini, pacaran menjadi identitas yang sangat dibanggakan. Biasanya seorang remaja akan bangga dan percaya diri jika sudah memiliki pacar. Sebaliknya remaja yang belum memiliki pacar dianggap kurang gaul. Karena itu, mencari pacar di kalangan remaja tidak saja menjadi kebutuhan biologis tetapi juga menjadi kebutuhan sosiologis. Maka tidak heran, kalau sekarang mayoritas remaja sudah memiliki teman spesial yang disebut "pacar". Lalu bagaimana pacaran dalam pandangan Islam? Istilah pacaran sebenarnya tidak dikenal dalam Islam. Untuk istilah hubungan percintaan antara laki-laki dan 
perempuan pranikah, Islam mengenalkan istilah "khitbah" (meminang). Ketika seorang laki-laki menyukai seorang perempuan, maka harus mengkhitbahnya dengan maksud akan menikahinya pada waktu dekat. Selama masa khitbah, keduanya harus menjaga agar jangan sampai melanggar aturan-aturan yang telah ditetapkan oleh Islam, seperti berduaan, memperbincangkan aurat, menyentuh, mencium, memandangi dengan nafsu, dan melakukan hubungan selayaknya suami istri. Ada perbedaan yang mencolok antara pacaran dengan khitbah. Pacaran tidak berkaitan dengan perencanaan pernikahan, sedangkan khitbah merupakan tahapan untuk menuju pernikahan. Persamaannya keduanya merupakan hubungan percintaan antara dua insan berlainan jenis yang tidak dalam ikatan perkawinan. Dari sisi persamaannya, sebenarnya hampir tidak ada perbedaan antara pacaran dan khitbah. Keduanya akan terkait dengan bagaimana orang mempraktikkannya. Jika selama masa khitbah, pergaulan antara laki-laki dan perempuan melanggar batas-batas yang telah ditentukan Islam, maka itu pun haram. Demikian juga pacaran, jika orang dalam berpacarannya melakukan hal-hal yang dilarang oleh Islam, maka hal itu haram. Jadi sebenarnya yang menjadi pijakan adalah bagaimana "pacarannya atau bagaimana dalam masa khitbahnya", bukan pada istilah pacaran atau khitbahnya. 


\section{DAFTAR PUSTAKA}

Abi Daud, Imam Al-Hafidz Sulaiman bin Ats'ats As-Sijistani, Sunan Abi Daud, Beirut-Libanon : Dar Al-Kutub Al-'Ilmiah, $275 \mathrm{H}$

Abuddin, Nata. Akhlak Tasawuf. Jakarta: Grafindo Persada, 2002.

Ahmadi, Wahid. Risalah Akhlak Panduan Perilaku Muslim Modern. Solo: Era Intermedia, 2004.

Amin, Ahmad. Etika (Ilmu Akhlak). Jakarta: Bulan Bintang, 1995.

Arikunto, Suharsimi. Prosedur Penelitian Suatu Pendekatan Praktek, Edisi Revisi V. Jakarta: Rineka Cipta, 2002.

Artoyo. Tenaga Kerja Perusahaan. Jakarta: Balai Pustaka, 1986.

Asikin, Zainal. Dasar-dasar Hukum Perburuhan. Jakarta: PT. Raja Grafindo Persada, 2004.

Azis, Moh. Ali. Ilmu Dakwah. Jakarta: Prenada Media, 2004.

Azwar, Saifuddin. Metode Penelitian. Yogyakarta: Pustaka Pelajar, 1995.

Bahar, Ahmad. Kisah Sukses dengan Kristalisasi Keringat. Jakarta: Penebar Swadaya, 2007.

Budiman, Kris. Menonton Sebagai Praktek Konsumsi. Yogyakarta: Galang Press, 2002.

Al-Bukhori, Jefri. Sekuntum Mawar untuk Remaja, Jakarta: Pustaka Al-Mawardi, 2006.

Burhan, Bungin. Metode Penelitian. Jakarta: Prenada Media, 2005

Burton, Greame. Membincangkan Televisi. Bandung: Jalasutra, 2002.

CD/DVD dakwah Ustadz Jefri Al-Bukhori

Effendi, Onong U. Ilmu Teori dan Filsafat Komunikasi. Bandung: PT. Cipta Aditya Bakti, 1990. 
Eggi, Sudjana. Buruh Menggugat Perspektif. Jakarta: Pustaka Sinar Harapan, 2003.

Erlina, Noor Lidiastutik. Hubungan Aktifitas Menonton Televisi Dengan Perilaku Keagamaan (Studi Analisis Pada Masyarakat Kec. Karimunjawa Kab. Jepara). Skripsi. Semarang : Fakda IAIN Walisongo, 2005.

Elvinaro dan Erdiyana. Komunikasi Massa Suatu Pengantar. Bandung: Rekatama Media, 2004.

Hadi, Sutrisno. Analisis Regresi. Yogyakarta: Andi Offset. Handoko, 2001.

Hidayati, Bern. Mendampingi Anak Menonton TV. Jakarta: Gramedia Pustaka Utama, 1996.

http://www.suaramerdeka.com/brev/07/04/2007/bel.html

http://www.Ust.Jefri.com.my

Iqbal. Pokok-pokok Materi Penelitian dan Aplikasinya. Jakarta: Ghalia Indonesia, 2002.

Kuswandi, Wawan. Komunikasi Massa Sebagai Analisis Media Televisi. Jakarta: Rineka Cipta, 1996.

Mahmud, Ali Abdul Halim. Akhlak Mulia. Jakarta: Gema Insani, 1995.

Martin. Motivasi. Yogyakarta: Kanisius, 1992.

Mulyana, Dedi, dan Idi Subandana. Bercinta dan Televisi. Bandung: Remaja Rosdakarya, 1997.

Muriah, Siti. 2000. Metodologi Dakwah Kontemporer. Yogyakarta: Mitra Pustaka.

Nasution, S. Metode Research. Jakarta: Bumi Aksara, 2003.

Nuruddin. Komunikasi Massa. Yogyakarta: Pustaka Pelajar, 2004.

- Sistem Komunikasi Indonesia. Jakarta: Grafindo Persada. Omar, Toha Yahya. 2004. Islam dan Dakwah. Jakarta: Al 
Mawardi Prima, 2004.

Poerwardaminto, WJS. Kamus Umum Bahasa Indonesia. Jakarta: Balai Pustaka, 1985.

Samiasih. Pengaruh Menonton Program Tolong di SCTV terhadap Sikap Solidaritas Mahasiswa Fakultas Dakwah Jurusan KPI (Angkatan 2002-2005) IAIN Walisongo Semarang. Skripsi. Semarang : Fakda IAIN Walisongo, 2006.

Singarimbun, Masri. Metode Penelitian Survei. Jakarta: LP3ES, 1989. Soehartono, Irawan. Metode Penelitian Sosial. Bandung: Remaja Rosdakarya, 1998.

Soekanto, Soerjono. Sosiologi Suatu Pengantar. Jakarta: Rajawali, 1982.

Syarifah, Fatimah. Pengaruh Menonton Bawang Merah Bawang Putih di RCTI terhadap Perilaku Keagamaan Remaja di Kec. Cepiring Kab. Kendal. Skripsi. Semarang : Fakda IAIN Walisongo, 2006.

Tuwu, Alimuddin. Televisi dan Islam. Yogyakarta: Citra Media. Winarni. 2003. Komunikasi Massa. Malang: UMM, 2007.

Yatimin, Abdullah. Studi Akhlak dalam Perspektif Al Qur'an. Jakarta: Amzah, 2007.

Zahrudin, dan Sinaga Hasanuddin. Pengantar Studi Akhlak. Jakarta: Grafindo Persada, 2004.

Zuhri, Thoha, dan Yahya. Metode Pengajaran Agama. Semarang: Pustaka Pelajar, 1999. 